\title{
In situ hybridization study of pro-opiomelanocortin (POMC) gene expression in human pituitary corticotrophs and their adenomas
}

\author{
Lucia Stefaneanu ${ }^{1}$, Kalman Kovacs ${ }^{1}$, Eva Horvath ${ }^{1}$, and Ricardo V. Lloyd ${ }^{2}$ \\ ${ }^{1}$ Department of Pathology, St. Michael's Hospital, University of Toronto, Toronto, Ontario, Canada \\ ${ }^{2}$ Department of Pathology, University of Michigan Medical Center, Ann Arbor, MI, USA
}

Received January 7, 1991 / Accepted March 11, 1991

\begin{abstract}
Summary. Pro-opiomelanocortin (POMC) mRNA was detected on paraffin sections by in situ hybridization (ISH) in corticotrophs of 12 nontumorous pituitaries, 11 functioning corticotroph, and 11 silent pituitary adenomas. ISH combined with immunocytochemistry for adrenocorticotrophic hormone (ACTH), a POMC-derived peptide, was also performed. ACTH immunoreactive cells of the anterior lobes and those invading the posterior lobe showed a high or moderate level of POMC mRNA that was not correlated with the intensity of ACTH immunoreactivity. Variable levels of POMC gene expression were present in Crooke's cells, corticotrophs suppressed by glucocorticoid excess. Most functioning corticotroph adenomas and silent subtype 1 adenomas had an intense hybridization signal and ACTH immunoreactivity. In silent subtype 2 and 3 adenomas, POMC mRNA had a diffuse low level or was absent; in these adenomas ACTH immunoreactivity was diffuse, restricted to some cells, or negative. The results indicate that POMC gene is expressed in both normal and suppressed nontumorous corticotrophs. Intense signals for POMC mRNA are found in most functioning corticotroph adenomas. The difference between POMC gene expression in silent 1 and silent 2 and 3 adenomas suggests that different mechanisms are responsible for the lack of endocrine activity.
\end{abstract}

Key words: Corticotrophs - In situ hybridization - Pituitary adenomas - Pro-opiomelanocortin

\section{Introduction}

The pituitary corticotroph is the major site of pro-opiomelanocortin (POMC) gene expression in man. In this cell type, the POMC molecule is processed post-transla-

Offprint requests to: L. Stefaneanu, Department of Pathology, St. Michael's Hospital, 30 Bond Street, Toronto, Ontario, M5B 1W8 Canada tionally mainly to adrenocorticotrophic hormone (ACTH), $\beta$-lipotropin and $\beta$-endorphin, which are readily identified by immunocytochemistry. Corticotrophs suppressed by glucocorticoid excess are called Crooke's cells and are characterized by massive accumulation of keratin immunoreactive intermediate filaments.

Most of the tumors arising in corticotrophs are associated with Cushing's disease or Nelson's syndrome due to increased production of ACTH. Electron microscopy shows that functioning corticotroph adenomas consist of well-differentiated, densely granulated cells. A few cases represent sparsely granulated, less differentiated adenomas or adenomas with Crooke's hyalinization (Kovacs and Horvath 1986; Horvath and Kovacs 1988). Some corticotroph adenomas are not associated with endocrine symptoms and, based on their ultrastructural features, have been divided into three subtypes: silent subtype 1 possesses an ultrastructure similar to that of the functioning variant; silent subtype 2 has small, spherical, tear- and heart-shaped granules of 150 $450 \mathrm{~nm}$ and is devoid of microfilaments; silent subtype 3 tumors contain abundant RER and SER profiles, very prominent, multifocal Golgi apparatus, small secretory granules $(<200 \mathrm{~nm})$ and nuclei with spheridia (Kovacs et al. 1978; Horvath et al. 1980; Hassoun et al. 1982; Horvath et al. 1988). The mechanisms responsible for the lack of ACTH excess in patients with such tumors are unknown. The investigation of POMC gene expression in nontumorous corticotrophs and their adenomas can contribute to a better understanding of the molecular events involved in hormone production.

The human POMC gene has been cloned and its DNA sequence determined (Chang et al. 1980; Whitfeld et al. 1982). In the pituitary, POMC mRNA has been detected by Northern blot and/or in situ hybridization (ISH) (Kelsey et al. 1986; Lewis et al. 1986; DeBold et al. 1988; Farquharson et al. 1990; Lloyd 1990). The usefulness of the ISH method for POMC mRNA demonstration in both functioning and silent corticotroph adenomas, using archival, paraffin-embedded specimens, has been proven by Lloyd et al. (1990). 
In the present study, the presence of POMC mRNA was investigated in nontumorous corticotrophs and all types of corticotroph adenomas and compared with their ACTH immunoreactivity and ultrastructural features.

\section{Materials and methods}

Tissues. Nontumorous pituitaries were obtained at autopsy ( 5 cases) of patients dying of nonendocrine diseases and at surgery of patients with the diagnosis of Cushing's disease ( 7 cases). Corticotroph adenomas were removed at surgery from patients with Cushing's disease ( 8 cases) and Nelson's syndrome (3 cases). Silent corticotroph adenomas included subtype 1 (4 cases), subtype 2 ( 3 cases) and subtype 3 (4 cases). All adenomas were previously diagnosed based on clinical, histologic, immunocytochemical and electron microscopic data.

Pieces of tumors were fixed in $10 \%$ buffered formalin and embedded in paraffin. Five-micron-thick sections were mounted on 3-aminopropylmethoxysilane-coated slides.

Probes. For POMC mRNA demonstration, an oligonucleotide probe (NEP-20/4, Dupont Canada Inc. Mississauga, Ont.) of 30 nucleotides (5'-d(CTT-GCC-CCA-GCG-GAA-GTG-CTC-CATGGA-GTA $\left(-3^{\prime}\right)$ was used. As positive-control probe, oligodeoxythymidylates, p(dT) 19-24 (The Midland Certified Reagent Co., Midland, Tex, USA) that detects poly-adenylated RNA sequences ( $\mathrm{Pr}-$ ingle et al. 1989) was applied. The probes were labeled by the $3^{\prime}$-end method with $\left({ }^{35} \mathrm{~S}\right) \mathrm{dATP} \alpha \mathrm{S}$ and terminal deoxynucleotidyl transferase using a kit (NEP-100, Dupont Canada Inc. Mississauga, Ont.) and purified with NENSOR ${ }^{\mathrm{TM}} 20$ cartridge included in the kit.

In situ hybridization. ISH was carried out on paraffin sections applying $3 \times 10^{5} \mathrm{CPM}$ of POMC probe and $1 \times 10^{6} \mathrm{p}(\mathrm{dT})$ probe as described previously (Kovacs et al. 1989; Lloyd et al. 1990). For ISH combined with immunocytochemistry, the avidin-biotin-peroxidase complex (ABC) method for ACTH was applied after $2 \times$ SSC washings. Anti-hACTH (NIDDKD, Bethesda, Md., diluted 1:2000, was used. Autoradiography was done with NTB-2 emulsion, diluted 1:1 with distilled water containing $0.3 \mathrm{M}$ ammonium acetate, as previously described (Kovacs et al. 1989). Slides were exposed to emulsion for 1 week at $4^{\circ} \mathrm{C}$ and then developed.

The specificity of hybridization was checked by: (1) predigestion of tissue sections with $100 \mathrm{ng} / \mathrm{ml}$ RNase A (Sigma, St. Louis, MO, USA); (2) competition study with tenfold excess of unlabeled probe; (3) human kidney used as negative control.

\section{Results}

In nontumorous pituitaries, the corticotrophs exhibited high levels of labeling for POMC mRNA (Fig. 1), which could not be correlated with the intensity of ACTH immunostaining. The corticotrophs extending into the posterior lobe expressed POMC mRNA as well (Fig. 2). The signal intensity was comparable or slightly lower than in the anterior lobe. The cells lining cavities representing pars intermedia labeled intensely for POMC mRNA.

Crooke's cells, found in nontumorous pituitaries obtained at surgery in association with functioning corticotroph adenomas, contained moderate to low levels of POMC mRNA (Fig. 3). A higher amount of labeling was found in Crooke's cells of autopsy pituitaries.

All functioning corticotroph adenomas expressed POMC mRNA. In well-differentiated, densely granulat- labeling prevailed (Fig. 4). Moderate densities of silver grains were noted in two adenomas, which contained not only ACTH but TSH and $\alpha$-SU of glycoprotein hormones immunoreactivities in a few cells (case 4) or only $\alpha$-SU in many cells (case 5). A moderate signal intensity was also present in a sparsely granulated corticotroph adenoma, an adenoma composed of large Crooke's cell population, and small cell population with signs of suppression and in an atypical corticotroph adenoma. The latter tumor was composed of small cells with moderately developed rough endoplasmic reticulum (RER) and Golgi regions; the small secretory granules $(150-300 \mathrm{~nm})$ with ovoid, rod, and heart shape were confined to the cell periphery; some adenoma cells showed extensive hyalinization. In functioning corticotroph adenomas associated with Nelson's syndrome, an intense or weak signal was present (Fig. 5). In functioning corticotroph tumors, the level of POMC gene expression could not be correlated with the amount of microfilaments in adenoma cells (Table 1).

In silent subtype 1 corticotroph adenomas, the intensity of labeling was similar to that encountered in functioning adenomas (Fig. 6). A low level or absence of POMC gene expression was found in silent subtype 2 adenomas (Fig. 7A). The silver granules were evenly distributed among adenoma cells despite the focal ACTH immunoreactivity. In silent subtype 3 adenomas, POMC mRNA presented a low level in one case with diffuse immunoreactivity for $\mathrm{ACTH}$; three cases were negative for POMC mRNA; one adenoma exhibited scattered ACTH immunoreactive cells; a variable number of cells immunoreactive for other adenohypophysial hormones was present in all three silent subtype 3 adenomas (Table 2).

The detection of poly-adenylated RNA in adenomas indicated the preservation of mRNA in formalin-fixed paraffin sections (Fig. 7B). However, the intensity of hybridization signal was not quantified since no information was available on the fixation and processing times of specimens. It is known that in paraffin-embedded tissue, a decrease in the mRNA amount occurs, depending on the duration of fixation and other parameters.

\section{Discussion}

Anterior pituitary corticotrophs are exposed to stimulatory and inhibitory control, mediated by hypothalamic and other factors and by direct glucocorticoid feedback from the adrenal gland (Keller-Wood and Dallman 1984; Lundbad and Roberts 1988). Long-term treatment with corticotropin-releasing hormone (CRH) or glucocorticoids have a direct influence on the synthesis and release of ACTH and other POMC-derived peptides (reviewed by Lundbad and Roberts 1988). The molecular mechanisms of transcriptional activation and inhibition of POMC gene are poorly understood.

The POMC mRNA can be demonstrated histologically by ISH methods. The comparison of ISH results with those of dot blot quantitation proved that ISH is an appropriate technic for detecting mRNAs both cytologically and quantitatively (Lewis et al. 1986). 

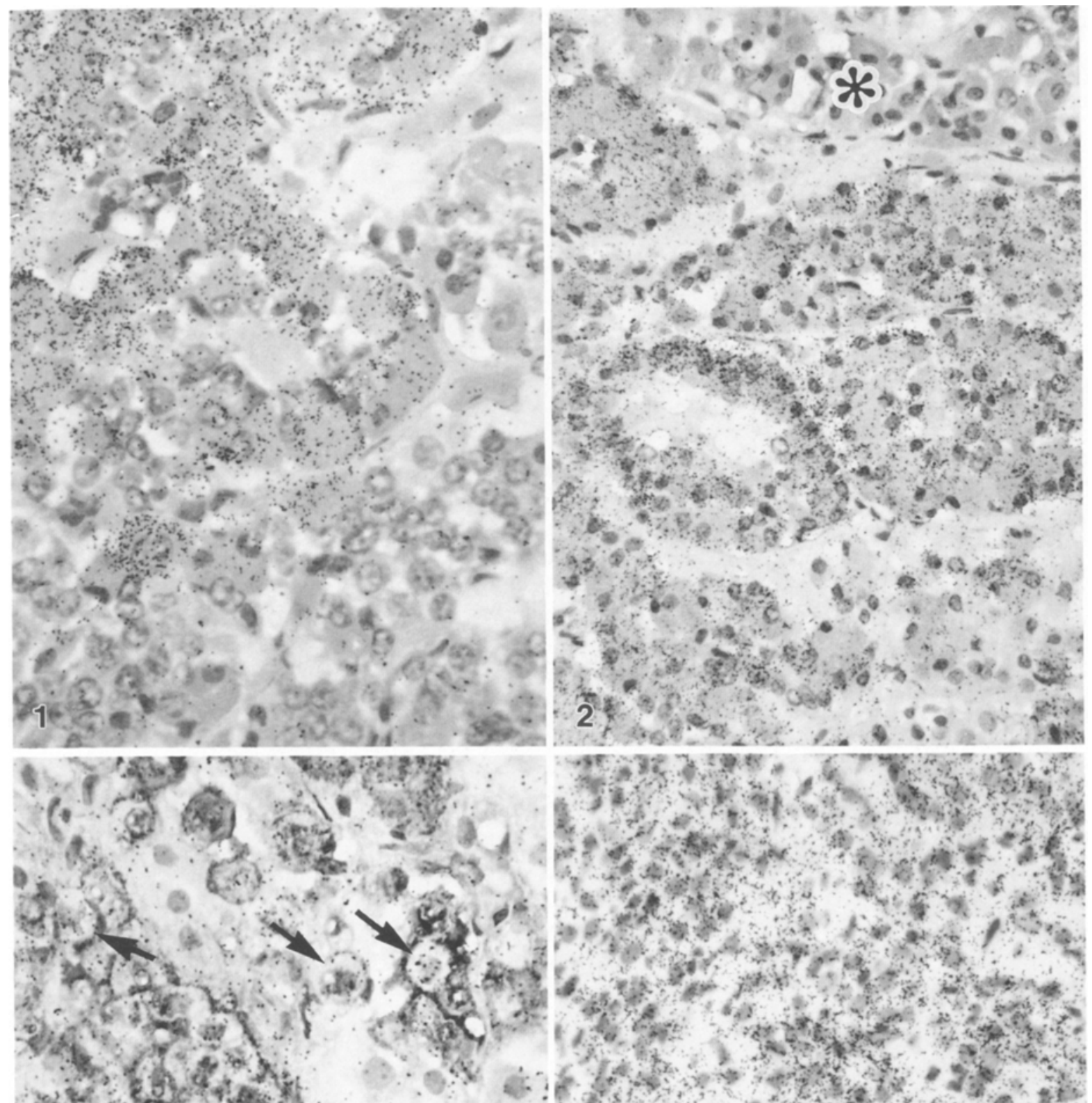

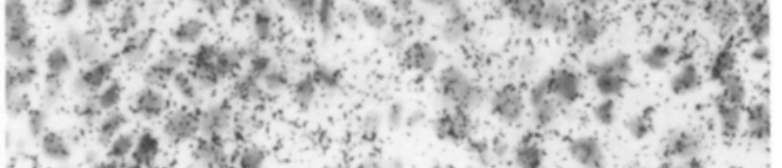
Whe

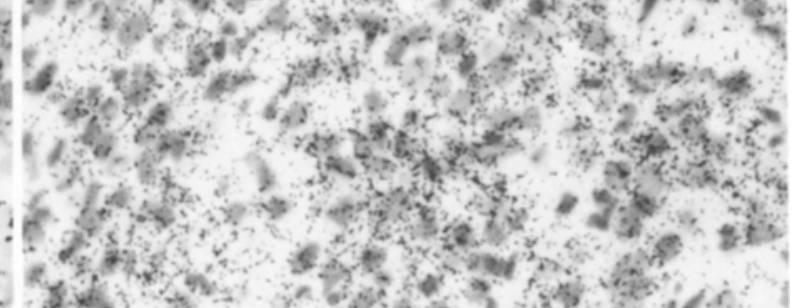
tiscosing
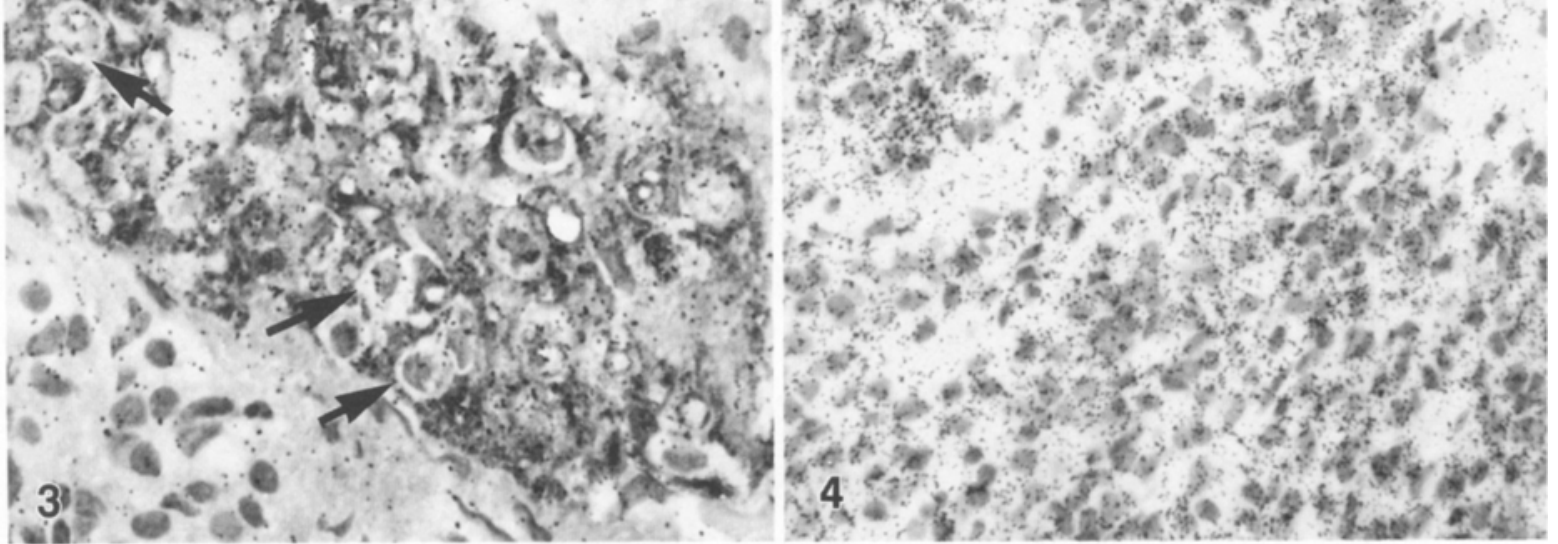

Fig. 1. Anterior lobe of an autopsy pituitary gland exhibits groups of cells containing intense signal for POMC mRNA. $\times 1400$

Fig. 2. Autopsy pituitary. Basophils extending into posterior lobe express POMC gene; in this field anterior lobe (asterisk) shows no POMC mRNA containing cells. $\times 1000$

Fig. 3. Nontumorous adenohypophysis of a patient with a functioning corticotroph adenoma contains Crooke's cells (arrows) with moderate to low POMC gene expression. ABC method for ACTH combined with ISH. $\times 1600$

Fig. 4. Functioning corticotroph adenoma associated with Cushing's disease exhibits intense labeling for POMC mRNA. $\times 1400$ 


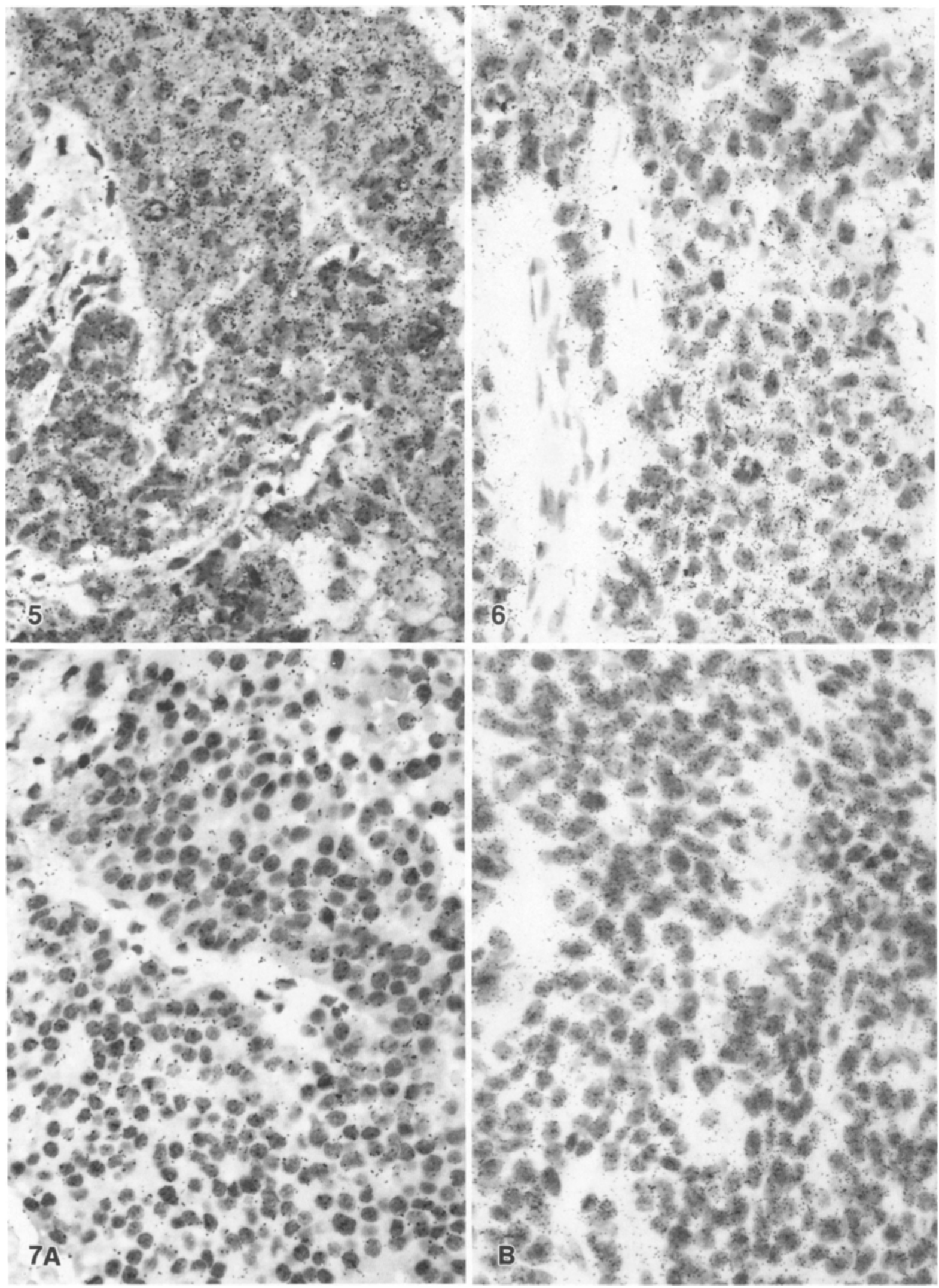

Fig. 5. Functioning corticotroph adenoma accompanied by Nelson's syndrome contains ACTH immunoreactive cells expressing POMC gene. $\times 1400$

Fig. 6. Silent subtype 1 corticotroph adenoma shows an intense hybridization signal in tumor cells. $\times 1400$

Fig. 7A, B. Silent subtype 2 adenoma presents very low hybridization for POMC mRNA (A). The preservation of mRNA in this specimen is proven by intense labeling with $\mathrm{p}(\mathrm{dT})$ probe that demonstrates poly-adenylated RNA $(\mathbf{B}) . \times 1600$ 
Table 1. Immunocytochemical, ultrastructural and in situ hybridization results in functioning corticotroph adenomas

\begin{tabular}{|c|c|c|c|c|}
\hline 1 & $\begin{array}{l}\text { Cushing's } \\
\text { disease }\end{array}$ & ACTH & $\begin{array}{l}\text { Typical } \\
\text { features }\end{array}$ &,++++ \\
\hline 2 & $\begin{array}{l}\text { Cushing's } \\
\text { disease }\end{array}$ & ACTH & $\begin{array}{l}\text { Typical } \\
\text { features }\end{array}$ &,+++++ \\
\hline 4 & $\begin{array}{l}\text { Cushing's } \\
\text { disease }\end{array}$ & $\begin{array}{l}\text { ACTH; TSH, } \\
\alpha \text {-SU: few cells }\end{array}$ & Typical features & ++ \\
\hline 5 & $\begin{array}{l}\text { Cushing's } \\
\text { disease }\end{array}$ & $\begin{array}{l}\mathrm{ACTH} \\
\alpha \text {-SU: many cells }\end{array}$ & Typical features & ++ \\
\hline 6 & $\begin{array}{l}\text { Cushing's } \\
\text { disease }\end{array}$ & ACTH & $\begin{array}{l}\text { Sparsely granula- } \\
\text { ted adenoma }\end{array}$ &,+++ \\
\hline 8 & $\begin{array}{l}\text { Cushing's } \\
\text { disease }\end{array}$ & $\mathrm{ACTH}$ & $\begin{array}{l}\text { Two cell popula- } \\
\text { tion: large } \\
\text { Crooke's cells; } \\
\text { small cells with } \\
\text { signs of } \\
\text { suppression }\end{array}$ & ++ \\
\hline 9 & $\begin{array}{l}\text { Nelson's } \\
\text { syndrome }\end{array}$ & ACTH & $\begin{array}{l}\text { Typical features; } \\
\text { no type } 1 \\
\text { filaments }\end{array}$ &,+++++ \\
\hline 10 & $\begin{array}{l}\text { Nelson's } \\
\text { syndrome }\end{array}$ & ACTH & $\begin{array}{l}\text { Typical features; } \\
\text { few type } 1 \\
\text { filaments }\end{array}$ & + \\
\hline
\end{tabular}

+ , Weak labeling; ++ , moderate labeling; +++ , intense labeling; ACTH, adrenocorticotrophic hormone; TSH, thyroid-stimulating hormone; LH, luteinizing hormone; $\alpha$-SU, alfa subunit of glycoprotein hormones

In nontumorous pituitaries ISH analysis combined with immunocytochemistry revealed that a high level of POMC mRNA was present in most ACTH immunoreactive cells, including those lining cavities of the intermediate lobe and those invading the posterior lobe. Variable amounts of POMC mRNA were found in Crooke's cells, which are corticotrophs suppressed due to glucocorticoid excess. The glucocorticoid feedback inhibition of ACTH release is rapid and progressive. The so-called delayed feedback occurs over hours to days and is accompanied by unresponsiveness to CRF and marked decreases in mRNA (Birnberg et al. 1983). Depending on the duration, glucocorticoid exposure can induce total unresponsiveness of the hypothalamic-pituitary-adrenal axis to extreme stimuli, as observed in partients with Cushing's syndrome or long-term therapeutic exposure to glucocorticoids (Jones 1979; Keller-Wood and Dallman 1984). In the human pituitary, the Crooke's cells are readily identified due to massive, ring-like accumulation of filaments. A few bundles of such filaments, measuring approximately $70 \mathrm{~nm}$ in width and representing cytokeratins disposed mainly around the nucleus, are unique morphologic markers of normal and suppressed human corticotrophs. In Crooke's cells, found in nontumorous adenohypophyses adjacent to a functioning corticotroph adenoma, low to moderate amounts of hybridization signal were detected, indicating that POMC gene transcription is not completely inhibited in such cells. In the corticotrophs with Crooke's change found in autopsy pituitaries, the signal intensity was comparable to that of normal corticotrophs. Since we do not have any data about the duration of glucocorticoid medication in these patients, the results cannot be assessed. Crooke's hyalinization is a reversible change that gradually disappears after normalization of blood glucocorticoid levels.

In most functioning corticotroph adenomas, a high level of POMC mRNA was identified. This is not surprising since it is known that in such tumors the feedback inhibition of ACTH by glucocorticoids is defective and that the elevated plasma cortisol does not decrease ACTH secretion. A lower POMC gene expression was observed in some rarely occurring corticotroph adenomas, such as the sparsely granulated variant, an atypical adenoma and an adenoma composed of two cell populations, a small cell component with scanty RER, inconspicuous Golgi regions and small secretory gran- 
Table 2. Immunocytochemical, ultrastructural and in situ hybridization results in silent adenomas

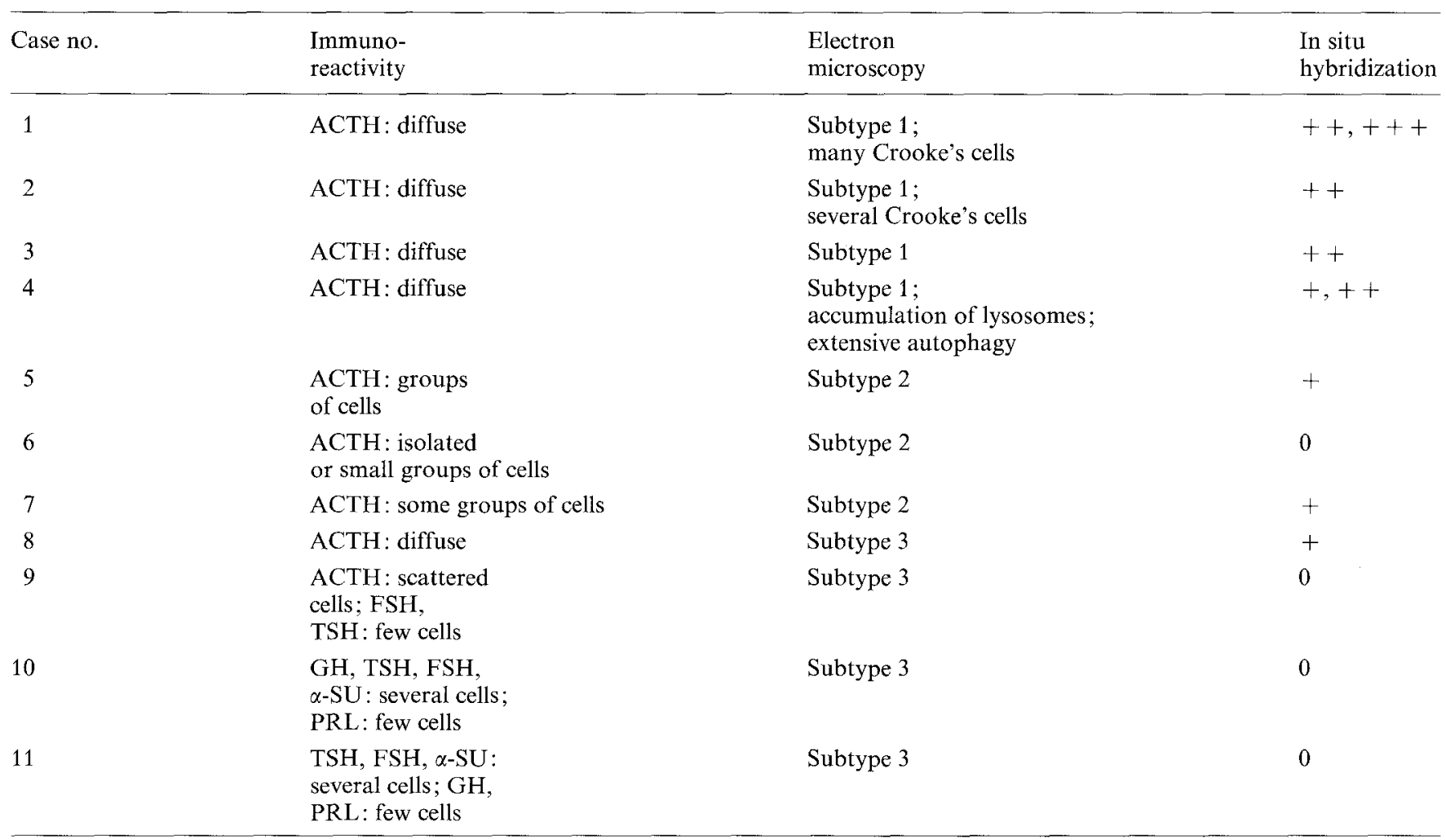

0 , Negative labeling; + , weak labeling; ++ , moderate labeling; +++ , intense labeling; FSH, follicle stimulating hormone; PRL, prolactin

ules and cells with Crooke's change. These results are in agreement with the clinical subtle form of Cushing's disease observed in such patients (Horvath and Kovacs 1988). In adenomas associated with Cushing's disease and Nelson's syndrome, the intensity of hybridization was not correlated with the amount of microfilaments present in adenoma cells in different cases.

In silent subtype 1 corticotroph adenomas, the level of POMC mRNA was comparable to that seen in functioning corticotroph adenomas. The ACTH immunoreactivity and the intensity of hybridization signal were evenly distributed among adenoma cells regardless of the percentage of cells with Crooke's change. Our results are in agreement with those of Lloyd et al. (1990) and suggest that, in this type of silent adenoma, the hormone synthesis is not inhibited at the transcription level. One can speculate that in such tumors a defective mechanism of POMC processing or peptides release exists. Abnormal processing of precursor peptide caused by point mutation(s) in POMC mRNA is one possibility. However, in one silent corticotroph adenoma, Nagaya et al. (1990) could not identify any abnormality in POMC size and coding sequence. In some corticotroph adenomas, gel chromatography analysis demonstrated the predominant secretion of a high molecular weight ACTH with a low biologic activity. In such tumors, the hormone release was not disturbed and the patients presented with or without Cushing's disease (Fuller et al. 1984; Reincke et al. 1987).

In silent subtype 2 and 3 adenomas, the POMC gene transcription was consistently low, indicating that a reduced rate of hormone synthesis can be responsible for the lack of endocrine symptoms. Morphologically, silent subtype 2 adenomas have some ultrastructural features of corticotrophs, such as the shape of cell and secretory granules, but they lack type 1 microfilaments; ACTH immunoreactivity is present in a variable number of cells. Silent subtype 3 adenomas initially were included in the group of corticotroph adenomas due to their immunoreactivity for ACTH and other POMC-derived peptides (Horvath et al. 1980). As more cases were investigated, it became evident that some adenomas contained no ACTH, and focal immunopositivity for other hormones was a frequent finding. Since silent subtype 3 adenoma is a well-defined entity by electron microscopy with no features reminiscent of corticotrophs, it is at present considered a separate group and its cellular origin remains obscure (Horvath et al. 1988). In situ hybridization studies indicate a low amount of POMC mRNA or none at all in silent subtype 3 adenomas. PRL gene expression was found in one case of silent subtype 3 tumor by Lloyd et al. (1990). The application of probes for glycoprotein hormones may contribute to prove the suggested potential of multidirectional differentiation of these tumors.

Acknowledgements. This work was supported in part by grant MT6349 awarded by the Medical Research Council of Canada and by St. Michael's Research Society. The authors thank Mr. R. Logan for technical assistance and Mrs. W. Wlodarski for secretarial work. 


\section{References}

Birnberg NC, Lissitzky JC, Hinman M, Herbert E (1983) Glucocorticoids regulate pro-opiomelanocortin gene expression in vivo at the levels of transcription and secretion. Proc Natl Acad Sci USA 80:6982-6986

Chang ACY, Cochet M, Cohen SN (1980) Structural organization of human genomic DNA encoding the pro-opiomelanocortin peptide. Proc Natl Acad Sci USA 77:4890-4894

DeBold CR, Menefee JK, Nicholson WE, Orth DN (1988) Proopiomelanocortin gene is expressed in many normal human tissues and in tumors not associated with ectopic adrenocorticotropin syndrome. Mol Endocrinol 2:862-870

Farquharson M, Harvie R, McNicol AM (1990) Detection of messenger RNA using a digoxigenin end labelled oligodeoxynucleotide probe. J Clin Pathol 43:424 428

Fuller PJ, Lim ATW, Barlow JW, White EL, Khalid BA, Copolov DL, Lolait S, Funder JW, Stockright JR (1984) A pituitary tumor producing high molecular weight adrenocorticotrophrelated peptides: clinical and cell culture studies. J Clin Endocrinol Metab 58:134-142

Hassoun J, Charpin C, Jaquet P, Lissitzky JC, Grisoli F, Toga $M$ (1982) Corticotropin immunoreactivity in silent chromophobe adenomas: a light and electron microscopic study. Arch Pathol Lab Med 106:25-30

Horvath E, Kovacs K (1988) Pituitary gland. Pathol Res Pract $183: 129-142$

Horvath E, Kovacs K, Killinger DW, Smyth HS, Platts ME, Singer W (1980) Silent corticotropic adenomas of the human pituitary gland: a histologic, immunocytologic and ultrastructural study. Am J Pathol 98:617-638

Horvath E, Kovacs K, Smyth HS, Killinger DW, Scheithauer BW, Randall R, Laws ER Jr, Singer W (1988) A novel type of pituitary adenoma: morphological features and clinical correlations. J Clin Endocrinol Metab 66:1111-1118

Jones MT (1979) Control of adrenocortical hormone secretion. In: James VHT (ed) The adrenal gland. Raven, New York, p 93

Keller-Wood ME, Dallman MF (1984) Corticosteroid inhibition of ACTH secretion. Endocr Rev 5:1-24
Kelsey JE, Watson SJ, Burke S, Aki H, Roberts JL (1986) Characterization of proopiomelanocortin mRNA detected by in situ hybridization. $J$ Neurosci $6: 38-42$

Kovacs K, Horvath E (1986) Tumors of the pituitary gland. In: Atlas of tumor pathology, Fasc. XXI, 2nd ser. Armed Forces Institute of Pathology, Washington DC, pp 1-264

Kovacs K, Horvath E, Bayley TA, Hassoun ST, Ezrin C (1978) Silent corticotroph cell adenoma with lysosomal accumulation and crinophagy. A distinct clinicopathologic entity. Am J Med $64: 492-499$

Kovacs K, Lloyd R, Horvath E, Asa SL, Stefaneanu L, Killinger DW, Smyth HS (1989) Silent somatotroph adenomas of the human pituitary. A morphologic study of three cases including immunocytochemistry, electron microscopy, in vitro examination and in situ hybridization. Am J Pathol 134:345-353

Lewis ME, Sherman TG, Burke S, Akil H, Davis LH, Arentzen R, Watson SJ (1986) Detection of proopiomelanocortin mRNA by in situ hybridization with an oligonucleotide probe. Proc Natl Acad Sci USA 83:5419-5423

Lloyd RV, Fields K, Jin L, Horvath E, Kovacs K (1990) Analysis of endocrine active and clinically silent corticotropic adenomas by in situ hybridization. Am J Pathol 137:479-488

Lundbad JR, Roberts JL (1988) Regulation of proopiomelanocortin gene expression in pituitary. Endocrinol Rev 9:135-158

Nagaya T, Seo H, Kuwayama A, Sakurai T, Tsukamoto N, Nakane T, Sugita K, Matsui N (1990) Pro-opiomelanocortin gene expression in silent corticotroph-cell adenoma and Cushing's disease. J Neurosurg 72:262-267

Pringle JH, Primrose L, Kind CN, Talbot IC, Lauder I (1989) In situ hybridization demonstration of polyadenylated RNA sequences in formalin-fixed paraffin sections using a biotinylated oligonucleotide poly d(T) probe. J Pathol 158:279-286

Reincke M, Allolio B, Saeger W, Kaulen D, Winkelmann W (1987) A pituitary adenoma secreting high molecular weight adrenocorticotropin without evidence of Cushing's disease. J Clin Endocrinol Metab 65:1296-1300

Whitfeld PL, Seeburg PH, Shine J (1982) The human pro-opiomelanocortin gene: organization, sequence, and interspersion with repetitive DNA. DNA 1:133-143 